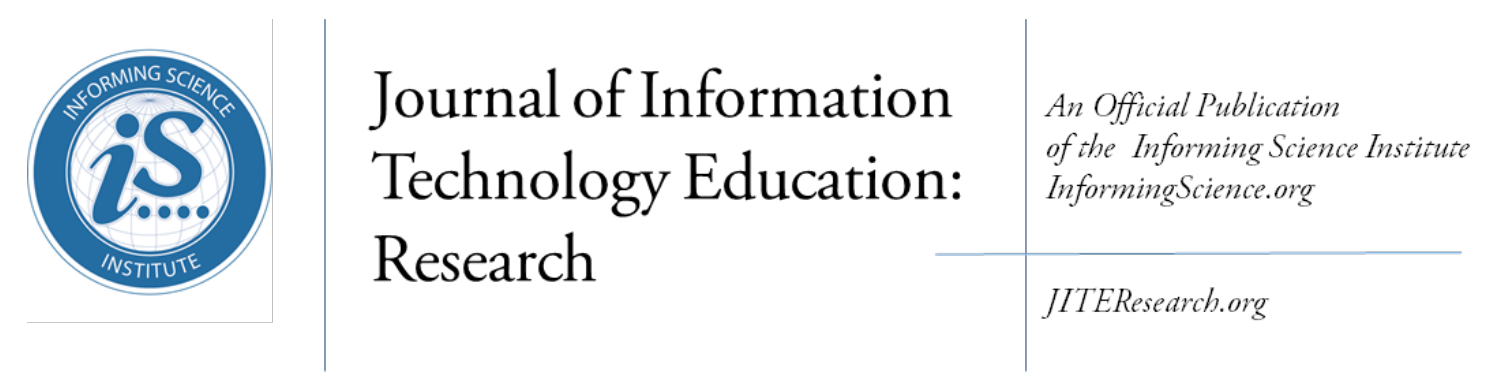

Volume 17, 2018

\title{
Teacher Presence and Social Presence IN VIRTUAL AND BLENDED COURSES
}

\author{
Gila Cohen Zilka * \\ Bar-Ilan University and \\ Achva Academic College, Israel \\ Revital Cohen \\ Ono Academic College, Israel \\ Ilan Daniels Rahimi \\ Ono Academic College, Israel \\ * Corresponding Author
}

gila.zilka@gmail.com

Revitalc@,bezeqint.net

revitalc@ono.ac.il

irahimi@,ono.ac.il

\begin{abstract}
Aim/Purpose

The purpose of the study was to examine the relationship between teacher presence and social presence on one hand, and feelings of challenge and threat, self-efficacy, and motivation among students studying in virtual and blended courses on the other.
\end{abstract}

Background

Physical separation between teacher and learners may lead to transactional distance, which should be reduced through teacher presence (TP) and social presence (SP). In this study we examined two types of courses, virtual courses (VCs) and blended courses (BCs).

Methodology

This is a mixed-method study. Participants completed a threat/challenge questionnaire, a motivation questionnaire, a self-efficacy questionnaire, and answered open-ended questions. The sample included 484 students from two academic institutions in the Israel.

Contribution
The study highlights the connection between critical factors involved in learn- ing and teaching in VCs and BCs (teacher presence, social presence, feelings of challenge and threat, self-efficacy, and motivation) from the point of view of students studying in VCs and BCs. Is there a correlation between teacher presence and social presence on one hand, and the perception of threat and challenge, motivation, and self-efficacy on the other in students studying in $\mathrm{VCs}$ and BCs?

\footnotetext{
Accepted by Editor Kathryn Mac Callum | Received: November 30, 2017 | Revised: March 8, 18, 25, April 8, May 17, 2018 | Accepted: May 22, 2018.

Cite as: Zilka, G. C, Cohen, R, \& Rahimi, I. D. (2018). Teacher presence and social presence in virtual and blended courses Journal of Information Technology Education: Research, 17, 103-126. https://doi.org/10.28945/4061

(CC BY-NC 4.0) This article is licensed to you under a Creative Commons Attribution-NonCommercial 4.0 International License. When you copy and redistribute this paper in full or in part, you need to provide proper attribution to it to ensure that others can later locate this work (and to ensure that others do not accuse you of plagiarism). You may (and we encourage you to) adapt, remix, transform, and build upon the material for any non-commercial purposes. This license does not permit you to use this material for commercial purposes.
} 
Findings A link was found between teacher presence and social presence on one hand and feelings of challenge and threat, self-efficacy, and motivation of students in VCs and BCs on the other. At the same time, it was found that the perceptions of motivation, challenge, and threat associated with VCs and BCs are interrelated, that is, students have similar perceptions in relation to both types of courses.

Recommendations It is preferable to create a learning environment that supports the learners for Practitioners and is attentive to their needs and to the creation of an active learning community. It has been found that these factors greatly influence the process and the quality of learning in the course.

Recommendations The study examined the subjective feelings of the students about the learning for Researchers process in virtual and blended environments. We recommend continuing to explore the characteristics of the virtual environment and of teaching methods in these environments.

Impact on Society The combination of virtual and blended learning environments in the learning process may lead to the realization of the educational vision of creating a learning environment that supports students and responds to their needs, enabling autonomous and collaborative learning while creating a learning community.

Future Research It is advisable to examine the issue from the perspective of the teachers in VCs and BCs to elucidate the topic from other angles.

Keywords blended course, challenge, motivation, learning community, self-efficacy, virtual course, social presence, teacher presence, threat, transactional distance

\section{INTRODUCTION}

The combination of virtual and blended learning environments in the learning process may lead to the realization of the educational vision of creating a learning environment that supports students and responds to their needs, enabling autonomous and collaborative learning while creating a learning community. In the present study we examined the relationship between teacher presence and social presence on one hand, and feelings of challenge and threat, self-efficacy, and motivation of students in virtual courses (VCs) and blended courses (BCs) on the other. A sense of challenge, motivation, self-efficacy, teacher presence, social presence, and a feeling of transactional distance reflect students' coping with the learning process, their satisfaction, and their persistence in learning (Moore, 1993; Zilka \& Zeichner, 2017).

The present study examined two learning environments, a virtual one and a blended one. A BC refers to a mixture of face-to-face and virtual learning. The learners meet face-to-face regularly, the course has an active website, discussions are held in a forum on the course website and continue face-toface, etc. This type of combination is expected to enrich the relationship between the teacher and the learner. Face-to-face meetings make possible immediate, unmediated interaction, based on verbal communication as well as non-verbal messages, such as facial expressions and body language, helping the teacher identify signs of distress, embarrassment, difficulties with the material being taught, and the like, which may require a response (Anderson, Rourke, Garrison \& Archer, 2001; Garrison \& Kanuke, 2004; Groen \& Li, 2005; Zeichner, \& Zilka, 2016; Zilka, \& Zeichner, 2017).

A VC takes place in a digital teaching environment that connects students and teachers who are physically separated from each other. The virtual environment enables learners to enhance the learning process and generally provides a fertile ground for exploration learning, combined materials (visual, 
audio, textual), the integration of tasks that require higher-order thinking, and so on. Because of their dynamic and diverse possibilities, VCs can lead to the development of a learning environment that encourages interpersonal communication and supports cooperation and space sharing (M. T. Cole, Shelley \& Swartz, 2014; Mbati \& Minnaar, 2015). The physical separation between teacher and learners, however, can lead to "transactional distance." This term, coined by Moore (1993), points to a psychological-communication gap that may emerge in the learning process between teacher and learners, creating a sense of threat, anger, gaps in understanding, or misconceptions of the learners about themselves and about the learning process. In Moore's opinion, the psychological-

communication gap is not constant, but a variable that can be reduced. Emphasis must be placed on the learners' perceptions: their needs, feelings, and difficulties (Kalogiannakis, 2010; Richardson et al., 2015; Zeichner \& Zilka, 2016; Zilka \& Zeichner, 2017).

The sample included 484 respondents from two academic institutions in Israel. All the participants in the study studied in VCs and BCs. The study examined the connection between teacher presence and social presence on one hand, and feelings of challenge and threat, self-efficacy, and motivation on the other, as perceived by learners studying in VCs and BCs. We examined the subjective feelings of students regarding the learning process in virtual and blended environments.

The research questions were:

1. What are the differences between students studying in VCs and BCs in their perceptions of threat and challenge, and in their motivation?

2. Is there a correlation between students' perception of self-efficacy and their perception of threat and challenge in VCs and BCs?

3. Is there a correlation between teacher presence and social presence on one hand, and the perception of threat and challenge, motivation, and self-efficacy on the other in students studying in $\mathrm{VCs}$ and BCs?

4. What are the critical factors that affect the perception of threat and challenge, and motivation in VCs?

5. How do students react to feelings of threat in VCs and BCs?

\section{TeACHer Presence ANd Social Presence}

\section{TEACHER PRESENCE}

Researchers (Allen, \& Seaman, 2010; Herbert, 2007; Liu, Magjuka, Bonk, \& Lee, 2007; Mandernach, 2009; Rovai, Wighting, \& Liu, 2005; Reupert, Maybery, Patrick, \& Chittleborough, 2009; Young \& Bruce, 2011) have sought to identify the critical factors that may lead to the improvement of the learning and of the instruction processes in VCs and BCs. They have found that the creation of a learning environment that supports the students and is attentive to their needs, and the creation of a "learning community" greatly influence the delivery of the course and the quality of both the learning and the teaching processes. Numerous studies (Anderson et al., 2001; Bransford, Brown, \& Cocking, 2000; Chickering \& Gamson, 2000; Garrison, 2007; Garrison et al., 2001) have shown that one of the most important factors in the success of teaching and learning processes is "teacher presence" in both VCs and BCs. Teacher presence is defined as meaningful communication for shaping, assisting in, and directing cognitive and social processes. Teacher presence encourages a climate of cooperation, community cohesion, and public discourse. It relies on forums and chats for conducting a dialog with students and between students, and encourages personal conversations between the teacher and the students. The concept of teacher presence includes three dimensions:

a. The personality of the teacher, which includes writing style and comments that may be inviting or distancing, labeling or constructive, rebuking or clarifying, and so on. Personality includes also the teacher's characteristics as a leader, and the style of communication the teacher adopts in the 
course; the personal and public feedback the teacher provides in the course, and the manner in which the feedback is formulated; the style of the personal dialogue taking place between the teacher and the student in their exchange of personal messages; the characteristics of the teacher as a leader who shapes communications in the course.

b. The social characteristics that the teacher creates in the forum and in the public posts; the community of learners the teacher builds; encouragement of interactions between learners; the public discourse created for the course; the use of the forum for conducting a discussion with and between students; the characteristics of the teacher as a social leader.

c. The teaching style of the teacher, as it gains expression on the website of the course; the characteristics of the teacher as a leader in learning.

Researchers ascribe great importance to feedback. Numerous studies conducted among students at academic campuses (Birch, 2013; Bruff, Fisher, McEwen, \& Smith, 2013; Francis \& Shannon, 2016; Leners \& Sitzman, 2006; Olivier, 2016; Poon, 2013; Tan, 2016) suggest that feedback is one of the most significant factors in the success of teaching and learning processes in VCs and BCs. Researchers have stressed the fact that the teacher must provide intellectual, emotional, and differential feedback. Significant feedback is likely to become an important motivational factor for students to continue their studies in the course. But despite the consensus between researchers that feedback is a significant factor, no such consensus exists regarding the correct amount of feedback that needs to be provided, or about the appropriate proportion of public feedback, visible to all students, vs. individual, differential feedback that takes place strictly between the student and the teacher (Leners \& Sitzman, 2006; Tempelaar, Rienties, \& Giesbers, 2015).

Researchers (Aspden \& Helm, 2004; Campbell, 2006; Horng, 2006) have found that students complained mainly about the lack of feedback from teachers on assignments completed and presented by students in VCs and BCs. They noted that teachers should offer students ways to communicate with them, such as email, personal messages, etc., to strengthen teacher presence in the eyes of the student and to create a learning environment in which possibilities expand and potential is realized (Dole \& Bloom, 2009; Kouzes \& Posner, 2003; Kyong-Jee \& Bonk, 2006; Leners \& Sitzman, 2006; Yoon, 2008).

\section{SOCIAL PRESENCE}

Researchers (Baker, 2010; Engstrom, Santo, \& Yost, 2008; Splitter, 2009; Zilka \& Zeichner, 2009) have defined social presence as the creation of a space for collaborative discourse, educational discourse, and free discourse, where students feel free to express their opinions and needs. Social presence enriches the personal and group learning processes. The teacher should create situations that encourage cooperation between students, ask them to respond in the forum to the posts of others, etc. In cases of confrontation between members of the group, the teacher must help them negotiate and reach an agreed-upon solution (Salman, 2006). The teacher must take active part in the discussion to encourage students to participate (Sharan, 2014).

Researchers (Billings \& Halstead, 2009; J. Cole, 2009; Feldman, 2007; Jelfs, Richardson, \& Price, 2009; Lawrence \& Sankey, 2008; Lee, 2008; Oliver, Osborne, \& Brady, 2009) have found that the unique characteristics of a virtual community are likely to create in students a sense of personal empowerment that enhances the learning process. The learning environment must enable a dynamic process in which students feel safe to be active participants (Pelz, 2004; Splitter, 2009).

Social presence may reduce the transactional distance that develops between students as a result of differences in understanding or misconceptions of students about themselves and about the learning process. A dialog between the teacher and the students and support for the learners and their needs may increase the students' sense of social presence. The presence of a learning community and engagement in the course are strongly related, as students develop a sense of closeness, as opposed to isolation, and feel the need to be more involved in learning. Researchers (Boerma, Stanley, \& 
Westhorp, 2007; Edwards, Perry, \& Janzen, 2011; Holley \& Dobson, 2008) have found that shared virtual learning experiences can increase student participation and instill in them a sense of a safe space, as opposed to one of anonymity. Researchers (Cameron, Morgan, \& Williams, 2009; Meyers, 2008; Rovai, 2007; Rovai \& Downey, 2010; Wang, 2007) have also found that forums brought their members closer, even if they have not met face-to-face. Students who collaborate can enrich their knowledge space by sharing their unique perspectives, ideas, and personal experiences. The process of collaboration creates a deep understanding of the content being studied, and the perspectives of others lead to an even deeper understanding of the material (Engstrom et al., 2008; Snyder, 2009). A teacher who encourages the creation of a learning community encourages communication between students, leading to meaningful learning (Liu et al., 2007).

Students' engagement in the course was defined as motivation to actively participate in the course. A virtual social community creates an environment that encourages joint activities, in-depth learning, and higher grades (Mandernach, 2009; Pate, Smaldino, Mayall, \& Luetkehans, 2009; Rovai, 2007; Witt, Wheeless, \& Allen, 2006). Rovai, Wighting, and Lucking (2004) found that a successful learning community is characterized by two main indicators: a social index (active involvement in the community) and a study index related to the content studied.

Researchers (Liu et al., 2007; Meyers, 2008; Oriogun, Ravenscroft, \& Cook, 2005; Pittman \& Richmond, 2008; Rovai, 2007; Robinson \& Hullinger, 2008; Shea, Li, \& Pickett, 2006; Young, 2006; Young \& Bruce, 2011) have argued that collaboration in virtual tasks provides students with opportunities to realize their potential through significant involvement, increases the degree of persistence, and reduces dropout rates from the course. When facing significant tasks, students who are actively involved in the learning community may develop a sense of belonging, as opposed to alienation and isolation, which helps them persevere and succeed in course assignments. Teachers should include learning activities that promote interaction and build a community, to create an ongoing presence.

In sum, teachers who encourage the creation of a learning community increase teacher presence and social presence, leading to a reduction of the transactional distance (Edwards et al., 2011; Pittman \& Richmond, 2008; Robinson \& Hullinger, 2008; Rovai, 2007; Young \& Bruce, 2011).

\section{Perceptions of the Situation: A Feeling of Threat or Challenge}

According to Lazarus (2000), in the encounter between humans and nature, humans can perceive the situation as either positive or stressful. This cognitive evaluation process is influenced by three sets of factors:

1. Characteristics of the situation: the extent to which the condition is familiar or vague.

2. Factors related to social norms: requirements, values, and customs.

3. Personality-related factors: pessimistic or optimistic, high or low self-esteem, high or low intelligence, ambitiousness or tendency to avoid failure.

A situation perceived as positive stimulates individuals to act, whereas a state perceived as stressful may trigger an emotional response of challenge or threat. When individuals feel threatened, their sense of uncertainty and lack of self-efficacy grow stronger, and they may avoid performing tasks or perform them poorly, focusing on defending themselves, preserving what they have, and so on. A sense of togetherness can reduce the threat and decrease non-adaptive responses. Lazarus noted that research has shown that different people are stressed to varying degrees when facing the same challenge. Researchers (Brown, Hughes, Keppell, Hard, \& Smith, 2015; Zilka. \& Zeichner, 2017) have found that a virtual learning environment constitutes a space loaded with feelings, in which students report frustration, anger, rage, joy, excitement, satisfaction, boredom, jealousy, hate, love, and affection with regard to the nature of learning. The virtual learning environment often contains an over- 
load of demands, leading to emotional arousal that may affect the learners' attitudes, behavior, and reactions.

\section{SELF-EFFICACY}

Researchers (Bandura, 1977, 1986, 1988, 1989; Schunk, 1983, 1984, 1989) have defined self-efficacy as the individuals' judgment of their ability to organize and successfully perform tasks and actions. According to research, self-efficacy affects the choice of activities, the effort, and the perseverance of the learner. Students with a sense of self-efficacy invest more effort and perseverance than those who doubt their ability. Self-efficacy derives from prior experience, feedback, and physiological arousal. If students feel that they will succeed in performing the task, their self-efficacy increases, and if they do not feel so, their self-efficacy decreases.

Schunk (1989) emphasized that the learner obtains information about his abilities also by comparison with others. The encounter in a face-to-face lesson exposes the learner to others. Watching fellow learners may arouse a sense that he can handle tasks, or alternatively, cause him to question his ability to cope with tasks. The teacher's feedback also affects the learner's perception and may reinforce either the learner's sense of ability to cope with the task or that of helplessness. Learning in a virtual or blended environment allows the learner to deal with tasks in a protected environment, where he is comfortable, and at a convenient time. The learner can observe the products of others, the teacher's assessment of the products of others, etc. But the "transactional distance" that provides a more protected environment to the learner, at times may weaken learners who need face-to-face interactions because their observing the learning process of others reinforces their sense that they are also capable of coping with the task.

\section{METHOD}

This is a mixed-method study. Participants answered a threat/challenge questionnaire that included open and closed questions, a motivation questionnaire, a self-efficacy questionnaire, and open questions.

\section{SAMPLE}

The sample included 484 respondents from two academic institutions in Israel. All the participants in the study studied in VCs and BCs. Students expressed their consent to participate in the study, complete the questionnaire, and participate in interviews. Most of the respondents were female $(70.2 \%)$, $46 \%$ aged $20-30$ years, $33 \%$ aged $30-40,21 \%$ aged 40 and over. $31 \%$ were in their first school year, $36 \%$ in the second year, and $33 \%$ in later years; $38.4 \%$ of participants studied in an academic track related to teaching, education, and social sciences, $31.2 \%$ studied in the business administration track, and $27.7 \%$ in organizational counseling studies.

\section{RESEARCH TOOLS}

1. The Threat/Challenge perception questionnaire was based on Lazarus and Folkman's (1984) questionnaire. It contains 13 statements, such as: "This situation makes you angry;" "This situation makes you nervous;" "This situation seems difficult for you;" "This situation threatens you;" "This situation will hurt you;" "This situation is worrisome;" "This situation is reassuring." The questionnaire focuses on factors that are clearly threatening/challenging. The following categories were identified: promoting knowledge and understanding, acquiring management tools, mastering innovative technology, course tasks and processes, and the output of the course (what I learned, what I took away from the course).

The students' perception of threat and challenge in relation to the various courses was assessed using three parameters, as detailed in Table 1 . The parameters were scored on a 7 -point response scale, $1=$ perception of low threat/challenge, $7=$ perception of high threat/challenge. The reliability of the 
indices ranged between Cronbach's $\alpha 0.815$ and 0.939 , indicating high internal consistency of the items.

Table 1: Perception of threat and challenge in VCs and BCs: main distribution and reliability indices (Cronbach's $\alpha$ ) and correlation coefficients (Pearson)

\begin{tabular}{|c|c|c|c|c|c|c|c|}
\hline \multirow{2}{*}{$\begin{array}{l}\text { Perception of } \\
\text { threat and chal- } \\
\text { lenge }\end{array}$} & \multirow{2}{*}{$\begin{array}{l}\text { Type of } \\
\text { course }\end{array}$} & \multicolumn{3}{|c|}{ Distribution index } & \multirow{2}{*}{$\begin{array}{c}\text { Reliability } \\
\text { Cronbach's } \alpha\end{array}$} & \multicolumn{2}{|c|}{$\begin{array}{c}\text { Correlation coeffi- } \\
\text { cients }\end{array}$} \\
\hline & & & $M$ & $S D$ & & $\begin{array}{l}\text { Negative } \\
\text { feelings }\end{array}$ & $\begin{array}{c}\text { Sense of } \\
\text { threat }\end{array}$ \\
\hline Negative feelings & \multirow{3}{*}{ Virtual course } & 2.77 & [1.00-7.00] & 1.44 & 0.908 & & \\
\hline Sense of threat & & 3.20 & [1.00-7.00] & 1.55 & 0.933 & $.839^{* *}$ & \\
\hline Sense of challenge & & 4.40 & [1.00-7.00] & 1.41 & 0.828 & $-.168^{* *}$ & $-.237^{* *}$ \\
\hline Negative feelings & \multirow{3}{*}{$\begin{array}{c}\text { Blended } \\
\text { course }\end{array}$} & 2.47 & [1.00-7.00] & 1.35 & 0.939 & & \\
\hline Sense of threat & & 2.79 & {$[1.00-7.00]$} & 1.40 & 0.939 & $.856^{* *}$ & \\
\hline Sense of challenge & & 4.49 & {$[1.00-7.00]$} & 1.37 & 0.815 & -0.039 & -0.048 \\
\hline
\end{tabular}

2. The Motivation questionnaire was based on Pintrich, Smith, Garcia, and McKeachie's (1991) questionnaire. It contains 27 questions scored on a 7 -point scale: $1=$ completely untrue, $7=$ very true. The questionnaire contained statements such as "In this type of course, I prefer the material to be a challenge for me so that I can learn new things;" "What brings me most satisfaction in this course is the attempt to understand the material as deeply as possible;" and "I'm sure that I'm able to understand even the most difficult parts of the reading material for this course."

The perception of motivation was estimated using 3 parameters, as detailed in Table 2. Measurement of these parameters was carried out on a 7 -point scale, $1=$ low perception of threat $/$ challenge, $7=$ high perception of threat/challenge.

Table 2: The perception of motivation in VCs and BCs: main distribution indices, reliability (Cronbach $\alpha$ ), and correlation coefficients (Pearson)

\begin{tabular}{|c|c|c|c|c|c|c|c|}
\hline \multirow{2}{*}{ Motivation } & \multirow{2}{*}{$\begin{array}{l}\text { Type of } \\
\text { course }\end{array}$} & \multicolumn{3}{|c|}{ Distribution index } & \multirow{2}{*}{$\begin{array}{c}\text { Reliability } \\
\text { Cronbach's } \alpha\end{array}$} & \multicolumn{2}{|c|}{ Correlation coefficients } \\
\hline & & & M & SD & & $\begin{array}{l}\text { Willingness to } \\
\text { face challenges }\end{array}$ & $\begin{array}{c}\text { Curiosity of } \\
\text { learning }\end{array}$ \\
\hline $\begin{array}{l}\text { Willingness to face } \\
\text { challenges }\end{array}$ & \multirow{3}{*}{ VC } & 5.15 & [1.67-7.00] & 1.05 & 0.893 & & \\
\hline $\begin{array}{l}\text { Curiosity about } \\
\text { learning }\end{array}$ & & 4.99 & [1.00-7.00] & 1.25 & 0.574 & $.766^{* *}$ & \\
\hline $\begin{array}{l}\text { Command of the } \\
\text { material studied }\end{array}$ & & 5.24 & [2.00-7.00] & 0.94 & 0.902 & $.813^{* *}$ & $.642^{* *}$ \\
\hline $\begin{array}{l}\text { Willingness to face } \\
\text { challenges }\end{array}$ & \multirow{3}{*}{$\mathrm{BC}$} & 5.45 & [2.00-7.00] & 0.99 & 0.913 & & \\
\hline $\begin{array}{l}\text { Curiosity about } \\
\text { learning }\end{array}$ & & 5.41 & [1.50-7.00] & 1.16 & 0.713 & $.827^{* *}$ & \\
\hline $\begin{array}{l}\text { Command of the } \\
\text { material studied }\end{array}$ & & 5.39 & [2.00-7.00] & 0.94 & 0.922 & $.851^{* *}$ & $.714^{* *}$ \\
\hline
\end{tabular}

$*^{* *} \mathrm{p}<.01 *_{\mathrm{p}}<.05$

The reliability of the parameters reflecting students' willingness to cope with challenges ranged between Cronbach's $\alpha 0.893$ and 0.913 , and the reliability of parameters reflecting the mastery of the course content ranged between Cronbach's $\alpha 0.902$ and 0.922 . These values indicate a high internal consistency of the items in both questionnaires. 
The reliability of the study-related parameter reflecting curiosity about the content under study was estimated as $\alpha=0.713$ for BCs and $\alpha=0.574$ for VCs.

3. The Self-Efficacy questionnaire was designed to measure the perception of ability to learn based on Bandura's model (Bandura, 1986). The questionnaire consists of 8 statements assessed on a 7 -point scale, ranging from $1=$ completely untrue to $7=$ very true. Respondents are asked to rate them according to the degree to which the statements describe them. The questionnaire distinguishes between three indices of self-efficacy in learning: academic, computer use (control of technology), and social. The characteristics of the concept of self-efficacy are summarized in Table 3 . The last variable reflects the perception of self-efficacy by the participants in the study. It was estimated on a 6-point scale, ranging from $1=$ low self-efficacy to $6=$ high self-efficacy. An estimated Cronbach's $\alpha=0.907$ indicates a high level of internal consistency of the items comprising the index.

Table 3: Perception of students' self-efficacy: Main distribution and reliability indices (Cronbach's $\alpha$ )

\begin{tabular}{|l|c|c|c|}
\hline Research variable & \multicolumn{2}{|c|}{ Distribution index } & $\begin{array}{c}\text { Reliability } \\
\text { Cronbach's } \alpha\end{array}$ \\
\hline Self-efficacy & $\mathrm{M}$ & SD & \\
\hline
\end{tabular}

4. Open Questions. The Open Questions based on previous studies (Horng, 2006; Jelfs, Richardson \& Price, 2009; Zeichner \& Zilka, 2016; Zilka \& Zeichner, 2017). The topics were derived from the closed questionnaires: "Do you regard computing and IT as an integral part of your studies? Please explain." "What do you find challenging in the course?" "What do you find threatening in the course?" "How did you respond to these feelings?" "What elicits negative feelings for you in the course?"

5. Other. Questions about personal status, demographic data, age, se,x and year of study.

\section{RESULTS}

This section presents quantitative and qualitative findings, in the following order.

Quantitative findings: perception of threat and challenge in VCs and BCs; perception of motivation in VCs and BCs; the concept of self-efficacy; factors affecting the perception of threat, challenge, and motivation in VCs and BCs.

Qualitative findings: perception of challenge in VCs and BCs; perception of threat VCs and BCs; responses to the feelings of threat in VCs and BCs; negative feelings in VCs and BCs; actions following negative feelings in VCs and BCs; feelings of anger and frustration in VCs.

\section{QUANTITATIVE FINDINGS}

\section{Perception of threat and challenge in VCs and BCs}

The results of the analyses comparing the perception of threat and of challenge in VCs and BCs are summarized in Table 4. The correlation coefficient analysis indicates a positive correlation between negative feelings toward VCs and toward BCs $(\mathrm{r}=712, \mathrm{p}<.01)$, between the feeling of threat in both types of courses $(\mathrm{r}=.623, \mathrm{p}<.01)$, and between the sense of challenge in VCs and in BCs $(\mathrm{r}=.853$, $\mathrm{p}<.01)$. The significance of these findings is that the perceptions of challenge and threat in VCs and BCs are interrelated, so that students have similar perceptions in relation to both types of courses. 
Table 4: Comparing the perception of threat and challenge in VCs and BCs

\begin{tabular}{|l|c|c|c|c|c|}
\hline $\begin{array}{l}\text { Perception of threat and } \\
\text { challenge }\end{array}$ & VC & BC & $\mathrm{r}$ & $\mathrm{t}$ \\
\hline Negative feelings & $M$ & 2.77 & 2.48 & \multirow{2}{*}{$0.712^{* *}$} & $5.908^{* *}$ \\
\cline { 2 - 6 } & $(S D)$ & $(1.44)$ & $(1.35)$ & & \\
\hline \multirow{2}{*}{ Feeling of threat } & $M$ & 3.19 & 2.80 & \multirow{2}{*}{$0.623^{* *}$} & \multirow{2}{*}{$6.692^{* *}$} \\
\cline { 2 - 4 } & $(S D)$ & $(1.54)$ & $(1.40)$ & & \\
\hline Feeling of chal- \\
lenge & $M$ & 4.39 & 4.48 & \multirow{2}{*}{$0.583^{* *}$} & 1.582 \\
\cline { 2 - 4 } & $(S D)$ & $(1.41)$ & $(1.36)$ & & \\
\hline
\end{tabular}

\section{Perception of motivation in VCs and BCs}

Results of the comparison of students' motivation characteristics in VCs and BCs are summarized in Table 5. The results of the comparison show a significant positive correlation between the willingness to face challenges in VCs and the willingness to face such challenges in BCs $(r=6.99, p<.01)$, the curiosity about learning in VCs and BCs $(\mathrm{r}=.533, \mathrm{p}<.01)$, and command of the material studied in VCs and BCs $(\mathrm{r}=.770, \mathrm{p}<.01)$.

Table 5: Comparing students' motivation in VCs and BCs

\begin{tabular}{|c|c|c|c|c|c|}
\hline \multicolumn{2}{|l|}{ Motivation } & $\mathrm{VC}$ & $\mathrm{BC}$ & $\mathrm{r}$ & $\mathrm{t}$ \\
\hline \multirow{2}{*}{$\begin{array}{l}\text { Willingness to } \\
\text { face challenges }\end{array}$} & $M$ & 5.45 & & \multirow{2}{*}{$0.699^{* *}$} & \multirow{2}{*}{$8.417^{* *}$} \\
\hline & $(S D)$ & (1.05) & $(0.99)$ & & \\
\hline \multirow{2}{*}{$\begin{array}{l}\text { Curiosity about } \\
\text { learning }\end{array}$} & $M$ & 4.98 & 5.41 & \multirow{2}{*}{$0.533^{* *}$} & \multirow{2}{*}{$7.975^{* *}$} \\
\hline & $(S D)$ & $(1.24)$ & $(1.16)$ & & \\
\hline \multirow{2}{*}{$\begin{array}{l}\text { Command of } \\
\text { the material } \\
\text { studied }\end{array}$} & $M$ & 5.23 & 5.39 & \multirow{2}{*}{$0.770^{* *}$} & \multirow[b]{2}{*}{$5.298^{* *}$} \\
\hline & $(S D)$ & $(0.94)$ & $(0.94)$ & & \\
\hline
\end{tabular}

\section{The concept of self-efficacy}

To determine the relationship between students' self-efficacy and how they perceive threats and challenges in both types of courses, we examined the correlation coefficients between the variables ( $\mathrm{Ta}$ ble 6). The results of the analysis indicate that there are significant negative correlations between the perception of self-efficacy and negative feelings in VCs $(\mathrm{r}=-233, \mathrm{p}<.01)$ and $\mathrm{BCs}(\mathrm{r}=-104, \mathrm{p}$ $<.05)$. Moreover, the analysis indicates that the strength of the correlation between self-efficacy and negative feelings is greater in VCs than in BCs $(z=2.016, p<.05)$. 
Table 6: Correlation coefficients between students' perception of self-efficacy and their perception of threat and challenge on one hand and motivation level on the other in VCs and BCs

\begin{tabular}{|c|c|c|c|c|}
\hline & & $\mathrm{VC}$ & $\mathrm{BC}$ & $\mathrm{z}$ \\
\hline \multirow{3}{*}{$\begin{array}{l}\text { Threat and } \\
\text { challenge }\end{array}$} & Negative feelings & $-.233^{* *}$ & $-.104^{*}$ & $2.016^{*}$ \\
\hline & Feeling of threat & $-.231^{* *}$ & $-.127^{* *}$ & 1.632 \\
\hline & Feeling of challenge & $.371^{* *}$ & $.274^{* *}$ & 1.647 \\
\hline \multirow{3}{*}{ Motivation } & $\begin{array}{l}\text { Willingness to face challeng- } \\
\text { es }\end{array}$ & $.569^{* *}$ & $.472^{* *}$ & $2.027^{*}$ \\
\hline & $\begin{array}{l}\text { Curiosity about learned ma- } \\
\text { terial }\end{array}$ & $.422^{* *}$ & $.370^{* *}$ & 0.937 \\
\hline & $\begin{array}{l}\text { Command of learned mate- } \\
\text { rial }\end{array}$ & $.491^{* *}$ & $.393^{* *}$ & 1.855 \\
\hline
\end{tabular}

\section{Factors affecting the perception of threat and challenge, and motivation in VCs}

To identify the factors that affect the perception of threat and challenge, and motivation in a virtual course, we conducted a linear regression analysis, in which students' perceptions in VCs were used as dependent variables, and students' background characteristics, as well as perception of their level of efficacy, served as independent variables.

An association was found between the perceptions of threat associated with VCs and BCs $(b=.283$, $\mathrm{p}<.01)$, as well as one between the perception of threat in VCs and negative feelings in the BCs (b = $.398, \mathrm{p}<.01)$. This finding indicates that the negative feelings associated with BCs also affect the negative feelings associated with VCs, as well as the feelings of threat associated with VCs. No correlation was found between the perception of threat in VCs and the parameters of motivation to learn, but there was a significant negative correlation between perception of threat in VCs and students' perception of self-efficacy $(b=-344, p<.01)$, which indicates that a higher perception of selfefficacy helps reduce the feelings of threat in VCs.

The analysis also revealed that the feeling of challenge in VCs is positively associated with the feeling of challenge in BCs $(\mathrm{b}=.655, \mathrm{p}<.01)$, and that the feeling of challenge is not related to other parameters of threat perception or to the various parameters of motivation to study in BCs. Finally, it was found that there is a positive correlation between the perception of challenge in VCs and the students' self-efficacy perception $(\mathrm{b}=.310, \mathrm{p}<.01)$, which indicates that a perception of higher selfefficacy leads to a greater feeling of challenge in VCs. 
Table 7: Linear regression of the dimensions of perception of threat and challenge and of motivation in a VC on background characteristics, perception of threat and challenge, and of motivation of a $\mathrm{BC}$, and self-efficacy perception

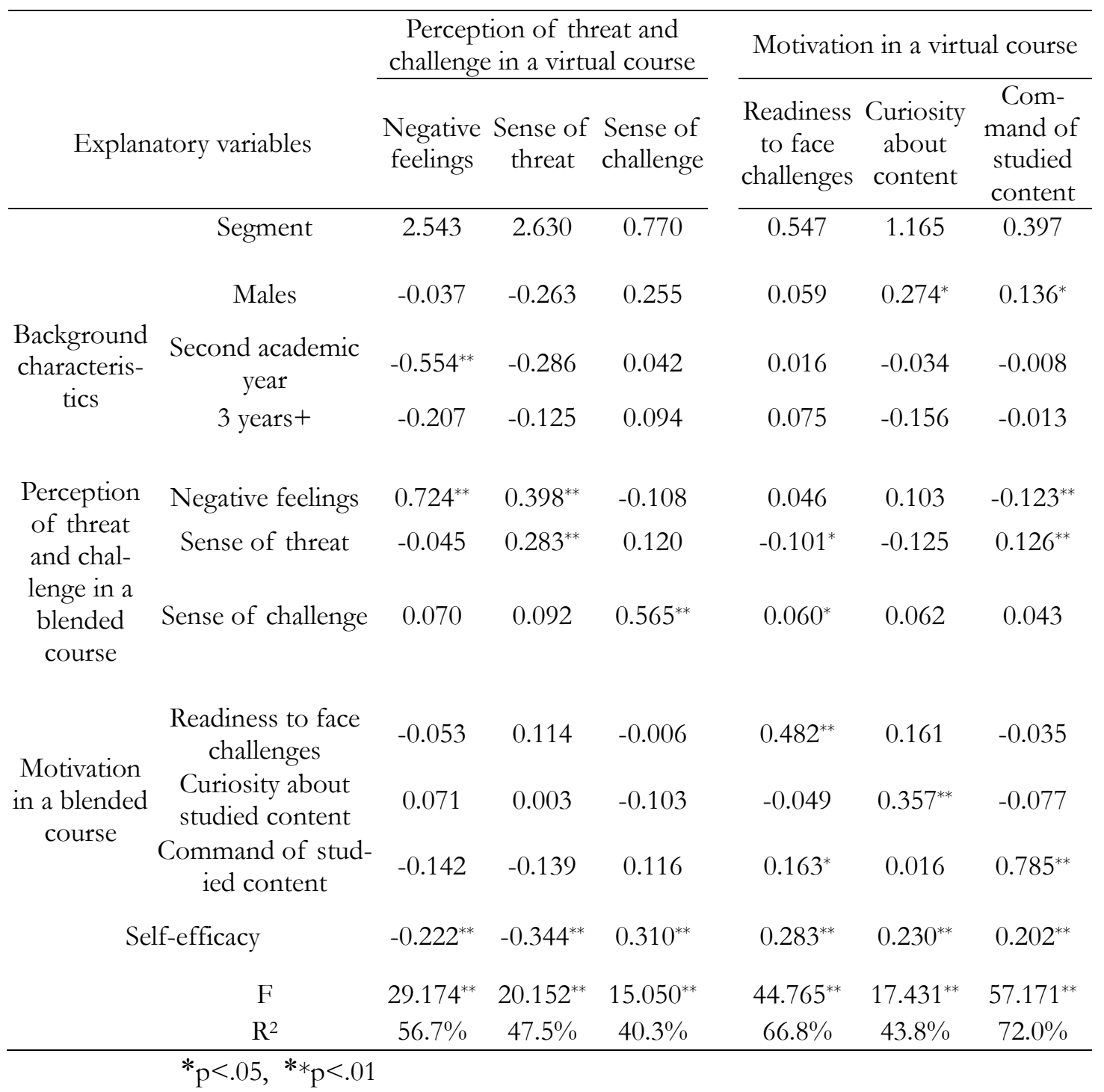

\section{QUALITATIVE ANALYSIS}

\section{The perception of challenge in VCs and BCs}

Figure 1 summarizes the respondents' perception of challenge in VCs and BCs. Analysis of the responses indicates that they fall into ten categories of reaction, in which the respondents related to the challenge in both types of courses.

Interaction with the teacher. Twenty three percent of respondents perceived the interaction with the teacher as a challenge in a BC (together with development of thinking skills, this was the most significant challenge), and 10\% of respondents perceived the interaction with the teacher as a challenge in a VC. Although the challenge of interacting with the teacher was more significant in $\mathrm{BCs}(\mathrm{t}$ $(483)=5.626, \mathrm{p}<.01)$, it was also significant in relation to VCs. 
Social interaction. Fifteen percent of respondents believed that social interaction is a challenge in a $\mathrm{BC}$, and $9 \%$ believed that social interaction is a challenge in a VC. Although the challenge of social interaction was more significant in a BC $(\mathrm{t}(483)=3.01, \mathrm{p}<.01)$, it appeared to be significant also in a VC.

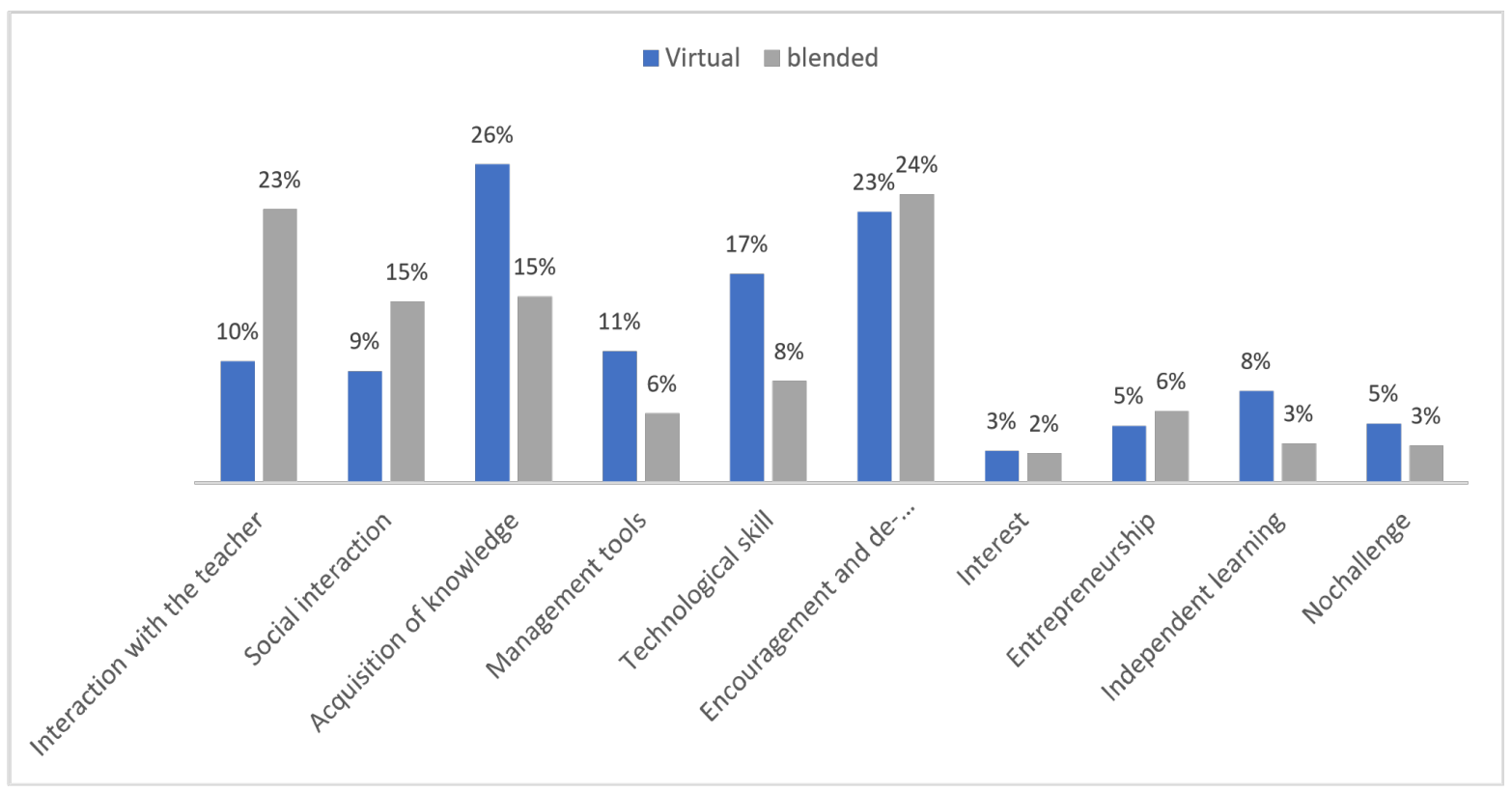

Figure 1: The perception of challenge in VCs and BCs

Thought development. The most significant challenge identified by respondents in both courses was thought development. It was found that the most significant challenge for students in both courses had to do with critical thinking and in-depth thinking skills. Although the challenge of independent learning was most significant in VCs $(\mathrm{t}(483)=3.492, \mathrm{p}<.01)$, the findings reinforced the conclusion that students consider independent learning, especially learning aimed at thought development, to be the main challenge in both types of courses.

Knowledge acquisition. Knowledge acquisition was a challenge in both types of courses. Twenty six percent of respondents believed that acquiring knowledge was a challenge in a VC, indeed, the most significant challenge that respondents have identified in connection with VCs. Similarly, 15\% of respondents believed that knowledge acquisition was a challenge in a BC. These attitudes reflect a more significant challenge $(\mathrm{t}(483)=4.770, \mathrm{p}<.01)$ in acquiring the knowledge in a VC than in a BC.

Management tools and technological proficiency. Eleven percent of respondents indicated that management tools were a challenge for them in connection with VCs. By comparison, only $6 \%$ of respondents indicated that management tools were a challenge in BCs. These attitudes reflect the fact that management tools raise a more significant challenge $(\mathrm{t}(483)=3.179, \mathrm{p}<.01)$ in VCs. Similar findings were revealed in connection with the challenge of technological proficiency. Seventeen percent of the respondents stated that technological proficiency was a challenge for them in connection with VCs. By comparison, only 8\% of respondents cited technological skills as a challenge in BCs. These attitudes reflect the fact that technological skills as a more significant challenge $(t=483)=$ $5.021, \mathrm{p}<.01$ ) for respondents in VCs than in BCs. 


\section{The perception of threat in VCs and BCs}

Figure 2 summarizes the main views expressed by respondents regarding the perceived threat in VCs and BCs. Analysis of the respondents' answers indicates that there are eleven categories of reaction in which the respondents related to the threat in both types of courses.

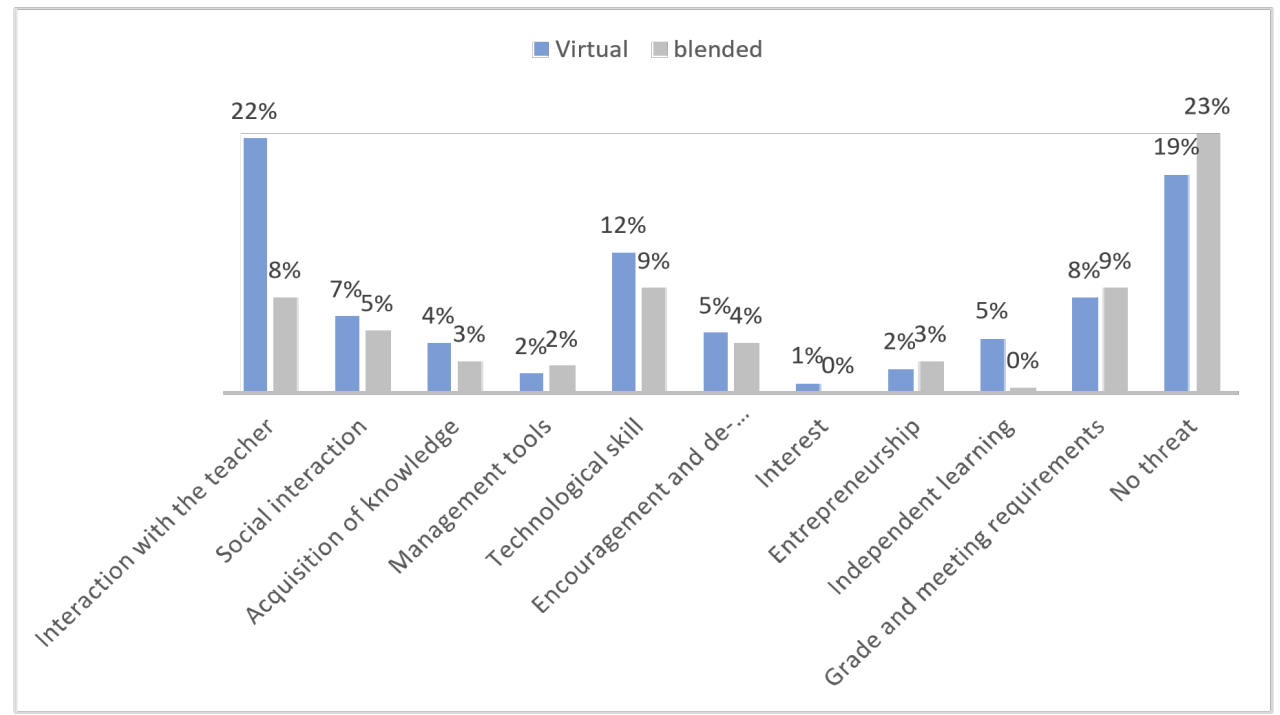

Figure 2: The perception of challenge in VCs and BCs

The prominent finding is that about a fifth of the respondents thought that there was no threat in the various courses.

The interaction with the teacher (or a lack thereof) was cited by $22 \%$ of respondents as a threat in relation to VCs. By contrast, only $8 \%$ of respondents noted the interaction with the teacher as a threat in BCs.

Twelve percent of respondents considered technological skills to be a threat in relation to VCs, and $9 \%$ in relation to BCs. At the same time, no difference was found in this regard in respondents' attitudes toward the two types of courses.

The percentage of respondents who mentioned thought development as a threat in courses ranged from $4 \%$ in BCs to $5 \%$ in VCs.

By contrast, $5 \%$ of respondents viewed independent learning to be a threat in VCs, whereas no respondent saw independent learning as a threat in the context of BCs $(\mathrm{t}(483)=4.464, \mathrm{p}<.01$.)

\section{Responses to feelings of threat in VCs and BCs}

The main attitudes and steps taken by respondents in response to threat in VCs and BCs are illustrated in Figure 3. The analysis of these attitudes points to the existence of six categories that characterize 287 the pattern of response and action prompted by respondents' feelings of threat in both types of courses.

The most significant finding of the analysis of the responses was that approximately $31 \%$ of participants turned to friends or acquaintances for help in response to the VC-related threat. This percentage is significantly higher $(\mathrm{t}(483)=9.258, \mathrm{p}<.01)$ than the percentage of respondents who sought the help of friends or acquaintances in response to the feeling of threat in BCs $(11 \%)$. 


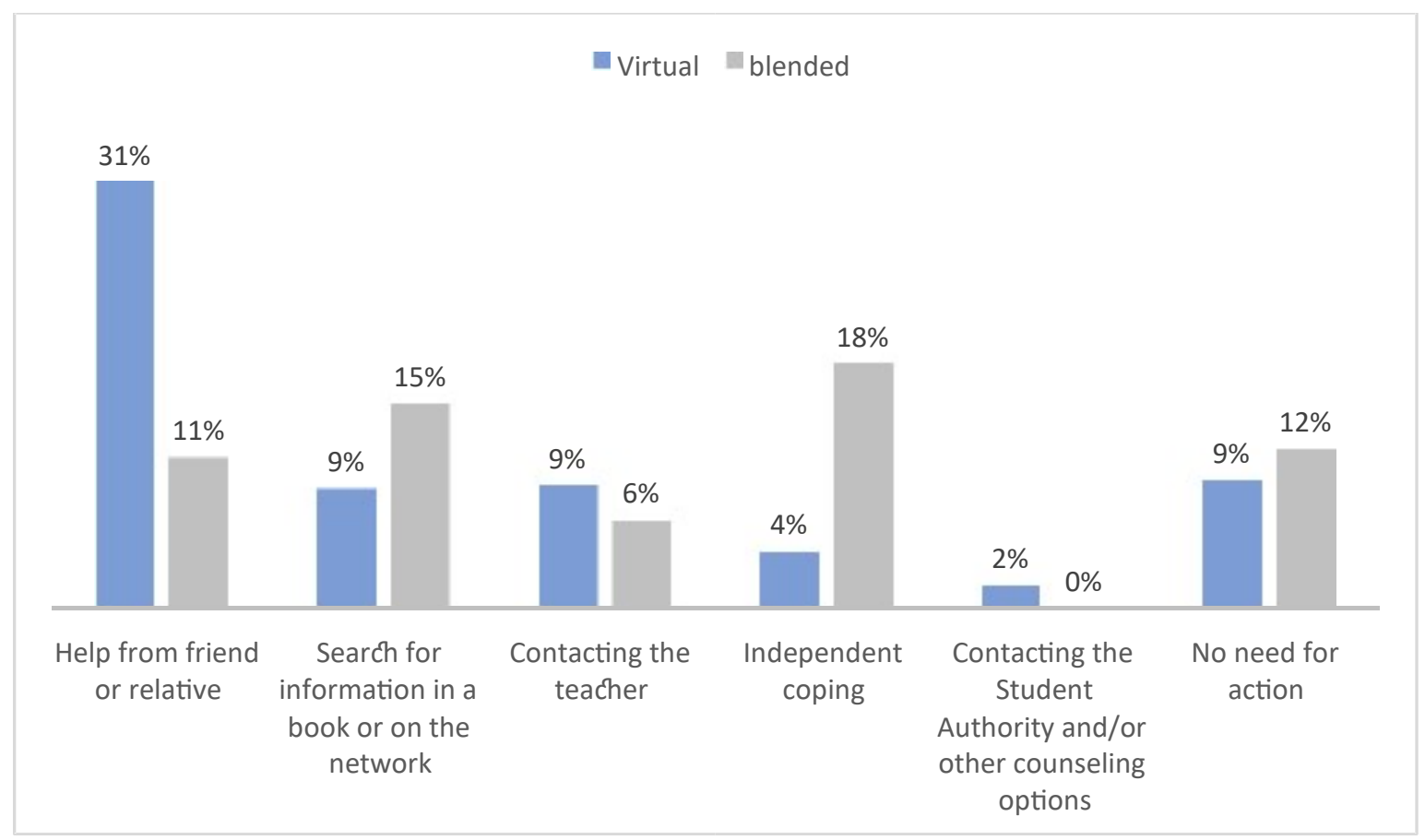

Figure 3: Response to feelings of threat in VCs and BCs

In response to the feeling of threat in $\mathrm{BCs}$, however, $15 \%$ of participants searched for information on the network or in the literature, compared with only $9 \%$ of participants in VCs ( $t(483)=3.578, \mathrm{p}$ $<.01)$.

No differences were found between the students in two courses in the rates of approaching the teacher in response to a feeling of threat. Nine percent of respondents indicated that they approached the teacher because of a feeling of threat in BCs, and $6 \%$ of the respondents made such an approach in VCs. Furthermore, 2\% of respondents in VCs indicated that they had approached the Dean of Students and other advisors in the educational institution in response to a feeling of threat (no respondent in $\mathrm{BCs}$ reported having done so).

Eighteen percent of the respondents indicated that they chose to face the feeling of threat in BCs by themselves. This percentage is significantly higher $((\mathrm{t}(483)=6.912, \mathrm{p}<.01)$ than that of students who chose to deal with such feelings by themselves in VCs (4\%).

Finally, $12 \%$ of the respondents noted that they did nothing regarding a feeling of threat in BCs, and $6 \%$ of respondents said that they acted similarly in VCs. Negative feelings in VCs and BCs

The main attitudes of the respondents to the negative feelings VCs and BCs are illustrated in Figure 4. The analysis of these attitudes points to the existence of eight categories that describe the respondents' feelings in both types of courses. 


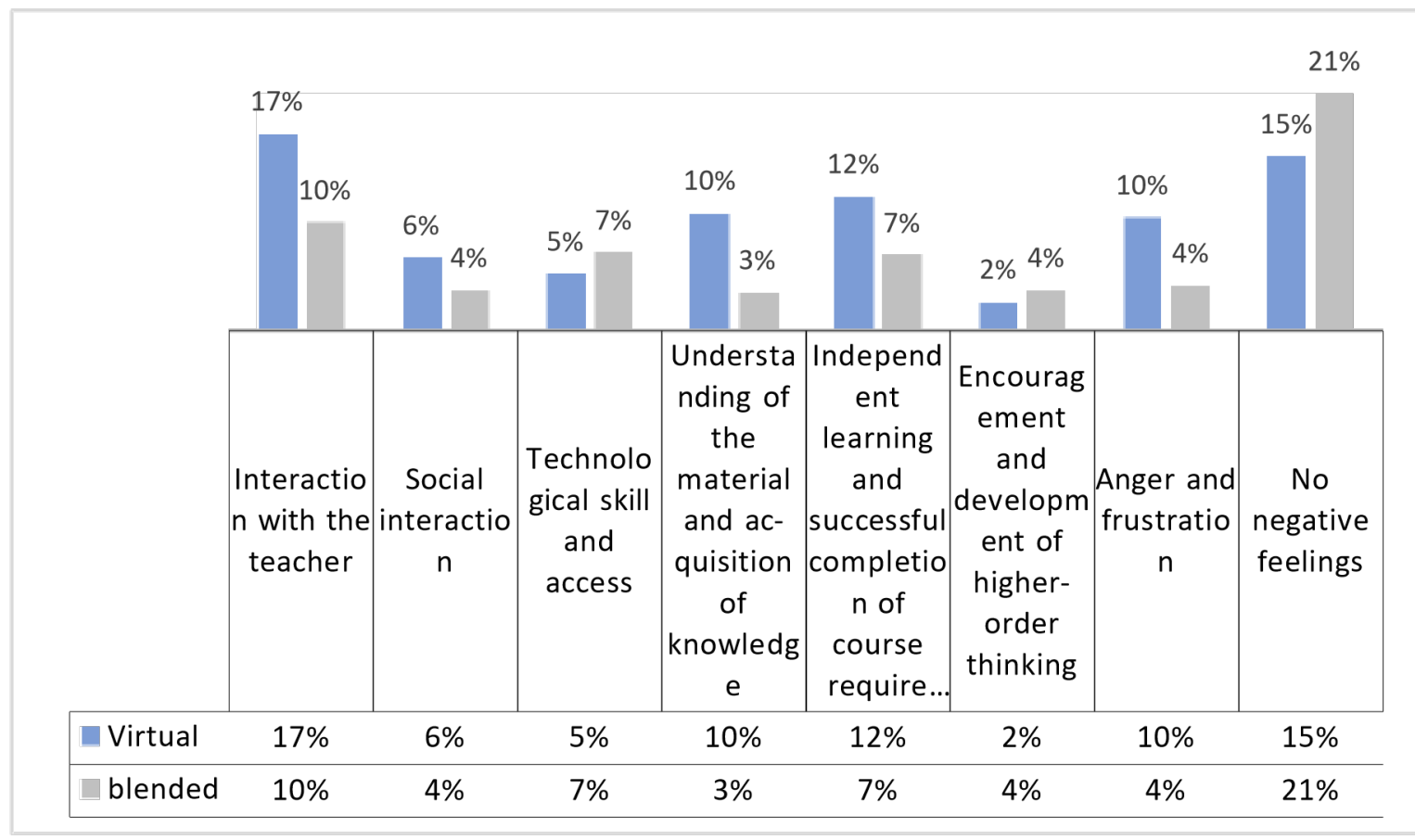

Figure 4: Negative feelings in VCs and BCs

Qualitative analysis shows that VCs provoked more negative feelings than BCs. By way of elimination, it was also found that a larger proportion $(\mathrm{t}(483)=3.333, \mathrm{p}<.01)$ of respondents pointed out that they had no negative feelings in BCs $(21 \%)$ than in VCs $(15 \%)$.

Seventeen percent of respondents mentioned negative feelings following their interaction with the teacher in VCs. This percentage is significantly higher $(\mathrm{t}(483)=4.117, \mathrm{p}<.01)$ than that of respondents who noted similar negative feelings in relation to BCs $(10 \%)$. A similar pattern, but of lesser intensity, is evident regarding negative feelings as a result of social interactions. It was found that $6 \%$ of respondents indicated having negative feelings as a result of social interaction in VCs. This percentage is significantly higher $(\mathrm{t}(483)=2.223, \mathrm{p}<.05)$ than that of respondents who indicated similar negative feelings in relation to BCs $(4 \%)$.

Ten percent of respondents experienced negative feelings in relation to the understanding of material and knowledge acquisition in VCs. This percentage is significantly higher $(\mathrm{t}(483)=4.822, \mathrm{p}<.01)$ than that of respondents who noted similar negative feelings in relation to BCs (3\%). Similarly, $12 \%$ of respondents reported negative feelings related to independent learning and meeting requirements in VCS. This percentage is significantly higher $(\mathrm{t}(483)=3.346, \mathrm{p}<.01)$ than that of respondents who mentioned such negative feelings in relation to BCs $(7 \%)$.

No differences were found in the negative feelings of respondents in both types of courses regarding technological skills and accessibility, or regarding the development of higher order thinking. By contrast, a higher percentage $(\mathrm{t}(483)=4.128, \mathrm{p}<.01)$ of respondents reported feelings of anger and frustration with regard to VCs $(10 \%)$ than the percentage of respondents who reported similar negative feelings with regard to BCs (4\%).

\section{Activity following negative feelings in VCs and BCs}

The main attitudes and steps taken by respondents in response to negative feelings in VCs and BCs are illustrated in Figure 5. The analysis of these attitudes points to the existence of six categories that describe the respondents' response patterns in both types of courses. 


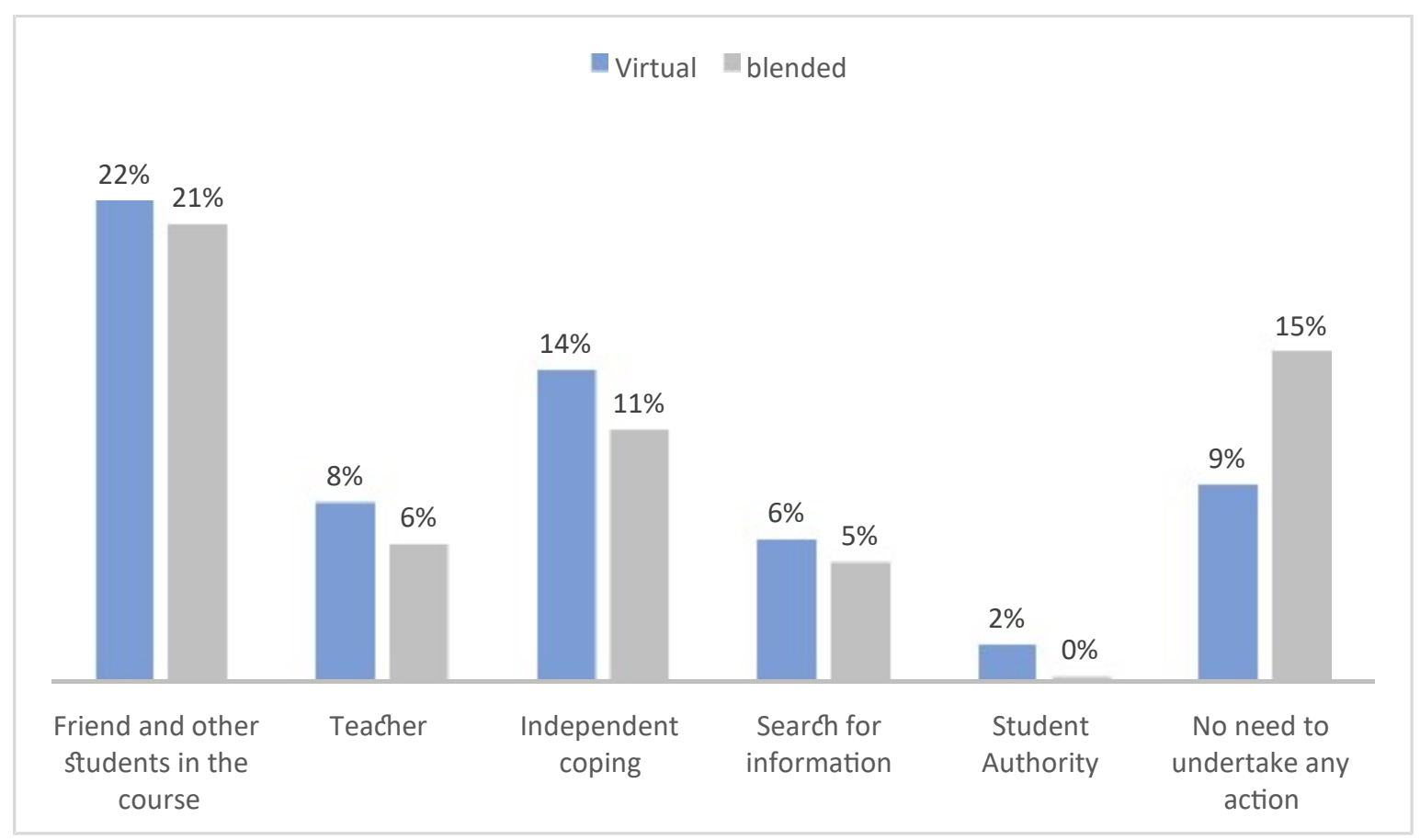

Figure 5: Activity following negative feelings in VCs and BCs

In both types of courses, about a fifth of the respondents approached a friend or another student for help in coping with the negative feelings in the courses. In addition, $14 \%$ of the respondents in VCs and $11 \%$ in BCs reported that they were coping with the negative feelings by themselves; $8 \%$ of respondents in VCs and 6\% in BCs reported that they contacted the teacher. Six percent of respondents in VCs and 5\% in BCs reported that they searched other sources for information. No differences between the courses were found in respondents' coping patterns in this respect.

It was also found that more respondents $(\mathrm{t}(483)=4.128, \mathrm{p}<.01)$ who participated in BCs $(15 \%)$ thought that there was no need for action in response to their negative feelings related to the course than did respondents who participated in VCs (9\%).Feelings of anger and frustration in VCs.

\section{Feelings of anger and frustration in VCs}

Respondents were asked to address the reason for feelings of anger and frustration they may have had in VCs. Their answers are summarized in Figure 6. the statement: "I felt anger/frustration in the virtual course because...”.

Eleven percent of respondents thought that the reason for their anger and frustration had to do with their interaction with the teacher. The responses of $12 \%$ of the participants indicated that the reason for these feelings was lack of understanding of the study material, and 13\% believed that the reason derived from the overall demands that created stress, frustration, and feelings of pressure. In addition, $6 \%$ of respondents reported that their feelings of anger and frustration in VCs stemmed from the (personal) drive to succeed in the course, mainly in achieving sufficiently high grades.

Only $6 \%$ of respondents thought that the feelings of anger and frustration were caused by technical or technological difficulties. Furthermore, $14 \%$ of respondents explicitly stated that they experienced no feelings of anger or frustration. 


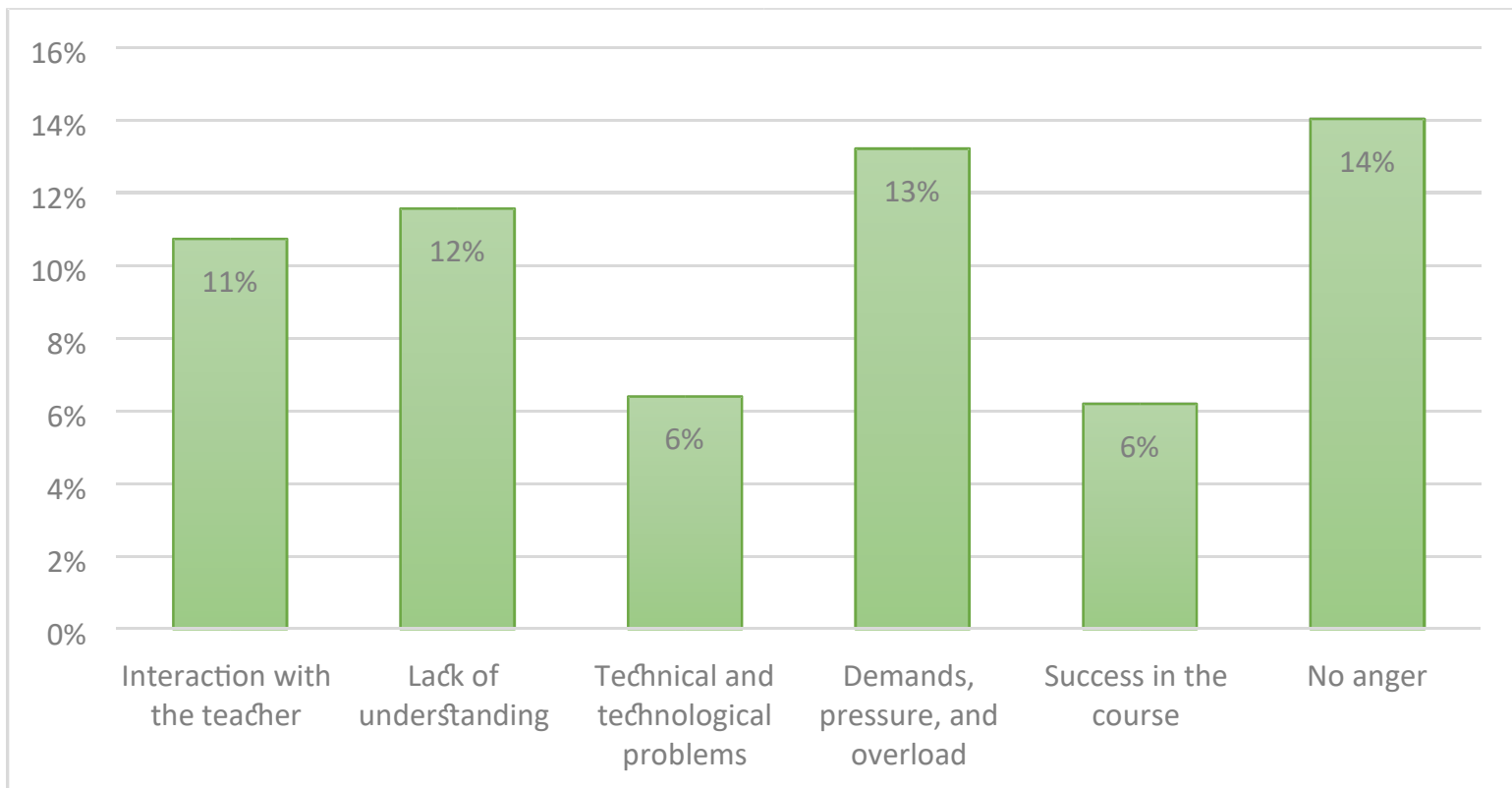

Figure 6: Reasons for feelings of anger and frustration in VCs

In general, no differences were found in the reasons for respondents' anger and frustration in VCs based on their academic year, other than the fact that $23 \%$ of respondents in advanced years of study noted the stress and pressure of requirements as being a reason for the anger and frustration they experienced in VCs. This percentage was higher than the percentage of respondents in the second academic year $(15 \%)$, and especially higher than that of respondents who cited this reason in the first academic year $(7 \%)$.

\section{DisCUSSION}

The study examined the relationship between teacher presence and social presence on one hand, and feelings of challenge and threat, self-efficacy, and motivation of learners studying in VCs and BCs on the other. The feelings of challenge, motivation, self-efficacy, teacher presence, social presence, and the feeling of occupational distance reflect the students' coping with the learning process, their satisfaction, and their persistence in learning.

Results show a connection between teacher presence and feelings of challenge and threat, selfefficacy, and the motivation of students in VCs and BCs. It was found that teachers who encouraged the creation of a learning community increased their teacher and social presence, which led to reduced transactional distance. Conversely, teachers, who did not encourage the creation of a learning community, maintained distance, and reduced feedback, increased the students' feeling of transactional distance. These results added new knowledge and confirmed the findings of previous studies (for example, Edwards et al., 2011; Pittman \& Richmond, 2008; Robinson \& Hullinger, 2008; Rovai, 2007; Young \& Bruce, 2011).

At the same time, it was found that the perceptions of motivation, challenge, and threat with regard to VCs and BCs are interrelated. In other words, students have similar perceptions about the two types of courses. It was also found that a perception of high self-efficacy contributes to reducing the feeling of threat and negative feelings in VCs and BCs. It was found that there is a positive correlation between the perception of challenge in VCs and BCs and the perception of self-efficacy of students, which indicates that a higher perception of self-efficacy leads to a stronger feeling of challenge in VCs and BCs. 
The findings indicate that students fall into two groups: about $80 \%$ feel comfortable in virtual and blended environments, feel motivated to attend these courses, and do not experience feelings of threat or negative feelings; about $20 \%$ experience feelings of threat, negative feelings, and difficulties interacting with the teacher and the group, and show low motivation to attend these courses.

\section{TEACHER PRESENCE}

Students reported various feelings about the nature of the interaction with the teacher and addressed in particular the issue of feedback. Researchers (Birch, 2013; Bruff et al., 2013; Francis \& Shannon, 2016; Olivier, 2016; Poon, 2013; Tan, 2016; Zilka \& Zeichner, 2017) have argued that feedback is one of the most significant factors in the success of the teaching process in VCs and BCs. The present study found that $18 \%$ of students claimed that they lacked concrete personal feedback on every assignment they submitted, which would help them determine whether the task was properly understood. They stated they wanted to receive specific guidance on how to correct their papers, and that it was better for them to receive immediate and specific feedback rather than general feedback at the end of the process. These students stated that they felt "forgotten" by the teacher. Failure to address the difficulties of these students may lead to feelings of alienation, lack of belonging, and inability to cope with the assignments, resulting in the students dropping out of the course, and even from the institution. The teacher should identify these students as early as possible, at the beginning of the course, and help them map their difficulty. If the reason for the difficulty is lack of skills needed to work in a virtual environment, the teacher must help students acquire these skills. If the difficulty stems from the lack of academic skills, such as the ability to find, process, and present information, the teacher must help students acquire these skills. A good interaction between teacher and student is one that results in transforming the feelings of helplessness into a sense of self-efficacy and the ability to collaborate within the environment.

It was found that the presence of the teacher is important for students for whom feedback reinforces the learning process and who feel helpless without feedback. It was also found that for students in need of intensive feedback, differential feedback is likely to lead to the development of individual abilities of students to assess their achievements and to reinforce their academic confidence. This finding emerged also from previous studies (Anderson et al., 2001; Birch, 2013; Bransford et al., 2000; Bruff et al., 2013; Chickering \& Gamson, 2000; Francis \& Shannon, 2016; Garrison et al., 2001; Olivier, 2016; Poon, 2013; Tan, 2016; Tempelaar et al., 2015; Zilka \& Zeichner, 2017).

This goal can be realized by monitoring the interaction between the teacher and the students for the purpose of helping the students become more independent. The teacher's feedback to students should include learning strategies, such as guidance in reading carefully the instructions for the assignment, reading carefully the other students' comments on the assignment, responding to other students' posts, etc. The amount of feedback should be adjusted to the individual student, transferring responsibility for the learning process to the student and developing learning strategies.

Some of the students maintained that they preferred clear, unambiguous assignments. The findings revealed a correlation between students' desire to receive clear assignments and their impression that the course was not well organized. If they received clear and unambiguous assignments, the course seemed comprehensible to them. When the teacher sought to challenge them, they became frustrated and developed negative feelings. When the students thought that the teacher rejected their request and did not provide them with clear instructions, the sense of threat and negative feelings increased. Students preferred to "obtain the knowledge" from the teacher instead of "building the knowledge" on their own, by processing and presenting the information. Teachers should give assignments that require higher-order thinking skills, but at the same time support the students who have difficulty coping with such tasks. The integration of virtual learning environments in the learning process may lead to the realization of an educational vision, whereby autonomous learners realize their personal potential. Therefore, the tasks assigned must require the application of higher-order learning skills, and the presentation of scholastic outcomes should take place before all participants. 
It was found that the sense of threat and negative feelings about VCs and BCs are more acute among first and second year students than among third and fourth year students. Therefore, teachers of VCs and BCs for students in their first and second year of studies should pay greater attention to teacher presence and provide differential feedback, if necessary.

\section{SOCIAL PRESENCE}

Social presence may reduce transactional distance, that is, lead to a reduction of the psychological communication gap resulting from learning in VCs and BCs, with respect to both the students themselves and to the learning process. A dialog between the teacher and the student and support for learners and their needs are likely to increase the sense of social presence among the students. Students referred to forums as a space for the development of a learning community. They mainly pointed out two types of forums in VCs and BCs: a free forum, open to all students, and forums concerning mandatory assignments.

The data showed that students who experienced feelings of threat and negative feelings toward free forums were the same ones who experienced feelings of threat and negative feelings toward VCs and BCs. These students preferred to study in a face-to-face environment. They felt alienated and had a sense of nonbelonging to the course, unwillingness to engage in a process of meaningful learning in a virtual environment, and especially fear of being exposed "to the eyes of all." The themes repeated by these students $(18 \%)$ again and again were: "The forums confuse me, lots of words;" "Everybody writes what they want, and it's hard to follow things;" "I would prefer that the teacher would give precise instructions and write exactly what needs to be done;" "Instead of giving precise instructions, the teacher responds to what other students wrote;" "Instead of answering the students in the forum the teacher should write what exactly needs to be done, so that there will be no misunderstandings;" "The forums only make me feel that I better avoid any involvement in virtual or blended courses;" "I feel that my achievements are lower in a virtual or blended course; it's easier for me to achieve high scores in face-to-face courses." The forums help a large number of students but interfere with others. Differential, intellectual, and emotional discourse on the part of the teacher with such students will enable these students to cope with tasks that are not unambiguous; the student must read these tasks, understand their meaning, seek solutions, process the material, and present their solutions in public.

The students noted that in certain VCs and BCs they were given compulsory assignments, in which all the students had to express an opinion in the forum. Some of the students admitted that it was difficult for them to express themselves, and that they felt threatened by the need to express their opinions and their feelings. Usually, in a face-to-face lesson, not every student must express an opinion or reveal personal feelings publicly. Intellectual and emotional support of students who feel exposed and vulnerable could allow students to apply higher-order learning skills than the ones they would have to demonstrate in face-to-face lessons.

\section{CONCLUSION}

In this study, we found that many students stated that the personality of the teacher is reflected in the sites of VCs and BCs, as well as in the way the teacher provides personal and public feedback. The teacher's style of writing encourages or discourages interaction between students and the development of a learning community in the course; increases or reduces distance. Individual and group instructions are written in a manner that increases or reduces distance, labels or builds, reprimands or clarifies, etc. The teacher should enable group integration, create rituals for shared learning, and emphasize that the voice of each student is important for the entire group. We found that teacher presence, the creation of a learning environment that supports the students and is attentive to their needs, and the creation of an active learning community greatly influenced the delivery of the course and the quality of the learning process. They also reduced transactional distance and aroused students' sense of belonging, as opposed to feelings of alienation and isolation. 
Implications of the study. It is preferable to create a learning environment that supports the learners and is attentive to their needs and to the creation of an active learning community. It has been found that these factors greatly influence the pro-cess and the quality of learning in the course. The combination of virtual and blended learning environments in the learn-ing process may lead to the realization of the educational vision of creating a learning environment that supports students and responds to their needs, enabling autonomous and collaborative learning while creating a learning community.

Future Research. It is advisable to examine the issue from the perspective of the teachers in VCs and BCs to elucidate the topic from other angles.

limitations of the study. The study examined the subjective feelings of the students about the learn-ing process in virtual and blended environments. We recommend continu-ing to explore the characteristics of the virtual environment and of teaching methods in these environments.

\section{REFERENCES}

Allen, I. E., \& Seaman, J. (2010). Learning on demand: Online education in the United States, 2009. The Sloan Consortium. Retrieved October 16, 2010 from http://www.sloanconsortium.org/sites/default/files/pages/learningondemand-7.pdf

Anderson, T., Rourke, L., Garrison, D. R., \& Archer, W. (2001). Assessing teaching presence in a computer conferencing context. Journal of Asynchronous Learning Networks, 5(2), 1-17. Retrieved April 3, 2004, from http://www.sloanc.org/publications/jaln/v5n2/pdf/v5n2 anderson.pdf

Ascough, R. (2007). Welcoming design: Hosting a hospitable online course. Teaching Theology and Religion, 10(3), 131-136. https://doi.org/10.1111/j.1467-9647.2007.00340.x

Aspden, L., \& Helm, P. (2004). Making the connection in a blended learning environment. Educational Media International, 41(3), 245-252. https://doi.org/10.1080/09523980410001680851

Baker, C. (2010). The impact of instructor immediacy and presence for online student affective learning, cognition, and motivation. The Journal of Educators online, 7(1), 1-30. https://doi.org/10.9743/JEO.2010.1.2

Bandura, A. (1977). Self-efficacy: Toward a unifying theory or behavioral change. Psychological Review, 84, 191215. https://doi.org/10.1037/0033-295X.84.2.191

Bandura, A. (1986). Social foundations of thought and action: A social cognitive theory. Englewood Cliffs, NJ: PrenticeHall.

Bandura, A. (1988). Self-regulation or motivation and action through goal systems. In V. Hamilton, G. H. Bower, \& N. H. Frijda (Eds.), Cognitive perspectives on emotion and motivation, (pp. 37-61). Dordrecht, the Netherlands: Kluwer. https://doi.org/10.1007/978-94-009-2792-6 2

Bandura, A. (1989). Human agency in social cognitive theory. American Psychologist, 44, 1175-1184. https://doi.org/10.1037/0003-066X.44.9.1175

Billings, D., \& Halstead, J. (2009). Teaching in nursing: A guide for faculty (3rd ed.). St Louis, MI: Saunders.

Birch, H. J. (2013). Feedback in online writing forums: Effects on adolescent writers. Teaching/Writing: The Journal of Writing Teacher Education, 5(1) 5.

Boerma, C., Stanley, M., \& Westhorp, P. (2007). Educators' perspective of online course design and delivery. Medical Teacher, 29, 758-765. https://doi.org/10.1080/01421590701477332

Bransford, J. D., Brown, A. L., \& Cocking, R. R. (Eds.). (2000). How people learn: Brain, mind, experience and schools. Washington, DC: National Academy Press.

Brown, M., Hughes, H., Keppell, M., Hard, N., \& Smith, L. (2015). Stories from students in their first semester of distance learning. Research in Open and Distance Learning - IRRODL, 16, 4. https://doi.org/10.19173/irrodl.v16i4.1647 
Bruff, D. O., Fisher, D. H., McEwen, K. E., \& Smith, B. E. (2013). Wrapping a MOOC: Student perceptions of an experiment in blended learning. Journal of Online Learning and Teaching, 9(2), 187.

Cameron, B. A., Morgan, K., \& Williams, K. C. (2009). Group projects: Student perceptions of the relationship between social tasks and a sense of community in online group work. The American Journal of Distance Education, 23, 20-33. https://doi.org/10.1080/08923640802664466

Campbell, T. (2006). Evolution and online instruction: Using a grounded metaphor to explore the advantageous and less advantageous characteristics of online instruction. Bulletin of Science, Technology \& Society, 26(5), 378-387. https://doi.org/10.1177/0270467606293296

Chickering, A. W., \& Gamson, Z. F. (2000). Development and adaptations of the seven principles for good practice in undergraduate education. In M. D. Svinicki (Ed.), Teaching and learning on the edge of the millennium: Building on what we have learned, (pp. 75-81). San Francisco, CA: Jossey-Bass.

Cole, J. (2009). Strategies for success: Teaching an online course. Rural Special Education Quarterly, 28(4), 36-40. https://doi.org/10.1177/875687050902800406

Cole, M. T., Shelley, D. J. \& Swartz, L. B. (2014). Online instruction, e-learning, and student satisfaction: A three year study. Research in Open and Distance Learning - IRRODL, 15, 6. https://doi.org/10.19173/irrodl.v15i6.1748

Dole, S., \& Bloom, L. (2009). Online course design: A case study. International Journal for the Scholarship of Teaching and Learning, 3(11), 1-11. https://doi.org/10.20429/ijsotl.2009.030111

Edwards, M., Perry, B., \& Janzen, K. (2011). The making of an exemplary online educator. Distance Education, 32(1), 101-118. https://doi.org/10.1080/01587919.2011.565499

Engstrom, M., Santo, S., \& Yost, R. (2008). Knowledge building in an online cohort. The Quarterly Review of Distance Education, 9(2), 151-167.

Feldman, K. A. (2007). Identifying exemplary teachers and teaching: Evidence from student ratings. In R.P. Perry \& J.C. Smart (Eds.), The scholarship of teaching and learning in higher education. An evidence-based perspective (pp. 93-143). New York: Springer. https://doi.org/10.1007/1-4020-5742-3 5

Francis, R., \& Shannon, S. J. (2016). Engaging with blended learning to improve students' learning outcomes. European Journal of Engineering Education, 38(4), 359-369. https://doi.org/10.1080/03043797.2013.766679

Garrison, D. R. (2007). Online community of inquiry review: Social, cognitive, and teaching presence issues. Online Community of Inquiry Review. Retrieved from http://www.people.ucalgary.ca/nvaghan/coiissues.pdf

Garrison, D. R., Anderson, T., \& Archer, W. (2001). Critical inquiry in a text-based environment: Computer conferencing in higher education. The Internet and Higher Education, 11(2), 1-14.

Garrison, D. R., \& Kanuke, H. (2004). Blended learning: Uncovering its transformative potential in higher education. The Internet and Higher Education, 7, 95-105. https://doi.org/10.1016/j.iheduc.2004.02.001

Groen, J., \& Li, Q. (2005). Achieving the benefits of blended learning within a fully online learning environment: A focus on synchronous communication. Educational Technology, 45(6), 31-37.

Herbert, M. (2007). Get your retention act together now: 8 pieces of advice. Distance Education Report, 11(9), 3-7.

Holley, D., \& Dobson, C. (2008). Encouraging student engagement in a blended learning environment: The use of contemporary learning spaces. Learning, Media, \& Technology, 33(2), 139-150. https://doi.org/10.1080/17439880802097683

Horng, J. L. (2006). On-line courses: Recommendations for teachers. Academic Exchange Quarterly, 10(4), 50-56. Retrieved from http://www.rapidintellect.com/AEQweb/

Jelfs, A., Richardson, J. T. E., \& Price, M. J. (2009). Student and tutor expectations of effective tutoring in distance education. Distance Education, 30(3), 419-435. https://doi.org/10.1080/01587910903236551

Kalogiannakis, M. (2010). Training with ICT for ICT from the trainee's perspective. A local ICT teacher training experience. Education and Information Technologies, 15, 3-17. https://doi.org/10.1007/s10639-008-9079-3

Kouzes, J., \& Posner, B. (2003). Academic administrator's guide to exemplary leadership. San Francisco, CA: JosseyBass. 
Presence in Virtual and Blended Courses

Kyong-Jee, K., \& Bonk, C. J. (2006, November 22-30). The future of online teaching and learning in higher education: The survey. Educause Quarterly, 28(4), 23-30. Retrieved from http://www.educause.edu/eq

Lawrence, J., \& Sankey, M. (2008). Communities of practice: A sphere of influence enhancing teaching and learning in higher education. Paper presented at Australian and New Zealand Communication Association Conference 2008.

Lazarus, R. S. (2000). Toward better research on coping. American Psychologist, 55(6), 665-673. https://doi.org/10.1037/0003-066X.55.6.665

Lazarus, R. S., \& Folkman, S. (1984). Stress, appraisal and coping. New York: Springer.

Lee, C. (2008). A neophyte about online teaching. Qualitative Inquiry, 14(7), 1180-1186. https://doi.org/10.1177/1077800408322226

Leners, D. W., \& Sitzman, K. (2006). Graduate student perceptions: Feeling the passion of caring online. Nursing Education Perspectives, 27(6), 315-321. Retrieved from http://www.nln.org/nlnjournal/index.htm

Liu, X., Magjuka, R. J., Bonk, C. J., \& Lee, S. (2007). Does sense of community matter? An examination of participants' perceptions of building learning communities in online courses. The Quarterly Review of Distance Education, 8(1), 9-24.

Mandernach, B. J. (2009, March). Three ways to improve student engagement in the online classroom. Online Classroom, 1-2.

Mbati, L., \& Minnaar, A. (2015). Guidelines towards the facilitation of interactive online learning programmes in higher education. Research in Open and Distance Learning - IRRODL, 16, 2. https://doi.org/10.19173/irrodl.v16i2.2019

Meyers, S. (2008). Using transformative pedagogy when teaching online. College Teaching, 56(4), 219-224. https://doi.org/10.3200/CTCH.56.4.219-224

Moore, M. G. (1993). Theory of transactional distance. In D. Keegan (Ed.), Theoretical principles of distance education (pp. 22-38). London, New York: Routledge.

Olivier, B. (2016). The impact of contact sessions and discussion forums on the academic performance of open distance learning students. The International Review of Research in Open and Distributed Learning, 17(6). https://doi.org/10.19173/irrodl.v17i6.2493

Oliver, K., Osborne, J., \& Brady, K. (2009). What are secondary student's expectations for teachers in virtual school environments? Distance Education, 30(1), 23-45. https://doi.org/10.1080/01587910902845923

Oriogun, P. K., Ravenscroft, A., \& Cook, J. (2005). Validating an approach to examining cognitive engagement within online groups. The American Journal of Distance Education, 19(4), 197-214. https://doi.org/10.1207/s15389286ajde1904 2

Pate, A., Smaldino, S., Mayall, H. J., \& Luetkehans, L. (2009). Questioning the necessity of nonacademic social discussion forums within online courses. The Quarterly Review of Distance Education, 10(1), 1-8.

Pelz, B. (2004). Three principles of effective online pedagogy. Journal of the Asynchronous Learning Network, 8(3), 33-46. Retrieved from http://sloanconsortium.org/publications/jaln main

Pintrich, P., Smith, D., Garcia, T., \& McKeachie, W. (1991). A manual for the use of the motivated strategies for learning questionnaire (MSLQ). National Center for Research to Improve Post secondary Teaching and Learning.

Pittman, L. D., \& Richmond, A. (2008). University belonging, friendship quality, and psychological adjustment during the transition to college. The Journal of Experimental Education, 76(4), 343-361. https://doi.org/10.3200/JEXE.76.4.343-362

Poon, J. (2013). Blended learning: An institutional approach for enhancing students' learning experiences. Journal of Online Learning and Teaching, 9(2), 271.

Reupert, A., Maybery, D., Patrick, K., \& Chittleborough, P. (2009). The importance of being human: Instructors' personal presence in distance programs. International Journal of Teaching and Learning in Higher Education, 21(1), 47-56. http://www.isetl.org/ijtlhe/ 
Richardson, J. C., Koehler, A. A., Besser, E. D., Caskurlu, S., Lim, J., \& Mueller, C. M. (2015). Conceptualizing and investigating instructor presence in online learning environments. Research in Open and Distance Learning - IRRODL, 16, 3. https://doi.org/10.19173/irrodl.v16i3.2123

Robinson, C. C., \& Hullinger, H. (2008). New benchmarks in higher education: Student engagement in online learning. Journal of Education for Business, 2, 101-108. https://doi.org/10.3200/JOEB.84.2.101-109

Rovai, A. (2007). Facilitating online discussions effectively. Internet \& Higher Education, 10(1), 77-88. https://doi.org/10.1016/j.iheduc.2006.10.001

Rovai, A., \& Downey, J. R. (2010). Why some distance education programs fail while others succeed in a global environment. Internet \& Higher Education, 13(3), 141-147. https://doi.org/10.1016/j.iheduc.2009.07.001

Rovai, A., Wighting, M. J., \& Liu, J. (2005). School climate. Quarterly Review of Distance Education, 6(4), 361-374.

Rovai, A., Wighting, M. J., \& Lucking, R. (2004). The classroom and school community inventory: Development, refinement and validation of a self-report measure for educational research. Internet and Higher Education, 7(4), 263-280. https://doi.org/10.1016/j.iheduc.2004.09.001

Salman, E. (2006). Taxonomy of collaborative e-learning. Cincinnati, OH: Union Institute \& University.

Schunk, D. H. (1983). Ability versus effort attributional feedback: Differential effects on self-efficacy and achievement. Journal of Educational Psychology, 75, 848-856. https://doi.org/10.1037/0022-0663.75.6.848

Schunk, D. H. (1984). Enhancing self-efficacy and achievement through rewards and goals: Motivational and informational effects. Journal of Educational Research, 78, 29-34. https://doi.org/10.1080/00220671.1984.10885568

Schunk, D. H. (1989). Self-efficacy and cognitive skill learning. Research on Motivation in Education, 3, 13-44.

Sharan, Y. (2014). Learning to cooperate for cooperative learning. Anales de Psicologia, 30(3), 802-807. https://doi.org/10.6018/analesps.30.3.201211

Shea, P., Li, C. S., \& Pickett, A. (2006). A study of teaching presence and student sense of learning community in fully online and web-enhanced college courses. The Internet and Higher Education, 9(3), 175-190. https://doi.org/10.1016/j.iheduc.2006.06.005

Snyder, M. M. (2009). Instructional-design theory to guide the creation of online learning communities for adults. TechTrends, 53(1), 48-56.

Splitter, L. J. (2009). Authenticity and constructivism in education. Studies in Philosophical Education, 28(2), 135151. https://doi.org/10.1007/s11217-008-9105-3

Tan, K. E. (2016). Using online discussion forums to support learning of paraphrasing. British Journal of Educational Technology, 48,6

Tempelaar, D. T., Rienties, B., \& Giesbers, B. (2015). In search for the most informative data for feedback generation: Learning Analytics in a data-rich context. Computers in Human Behavior, 47, 157-167. https://doi.org/10.1016/j.chb.2014.05.038

Wang, M. (2007). Designing online courses that effectively engage learners from diverse cultural backgrounds. British Journal of Educational Technology, 38(2), 294-311. https://doi.org/10.1111/j.1467-8535.2006.00626.x

Witt, P. L., Wheeless, L. R., \& Allen, M. (2006). The relationship between teacher immediacy and student learning: A meta-analysis. In B. M. Gayle, R. W. Preiss, N. Burrell \& M. Allen (Eds.), Classroom communication and instructional processes. Advances through meta-analysis (pp.149-168). London: Lawrence Erlbaum.

Yoon, B. (2008). Uninvited guests: The influence of teacher's roles and pedagogies of English language learners in the regular classroom. Educational Research Journal, 45(2), 495-522. https://doi.org/10.3102/0002831208316200

Young, S. (2006). Student views of effective online teaching in higher education. American Journal of Distance Education, 20(2), 65-77. https://doi.org/10.1207/s15389286ajde2002 2

Young, S., \& Bruce, M. A. (2011). Classroom community and student engagement in online courses. Journal of Online Learning and Teaching, 7(2). http://jolt.merlot.org/vol7no2/young 0611.htm 
Zeichner, O., \& Zilka, G. (2016). Feelings of challenge and threat among pre-service teachers studying in different learning environments - Virtual vs. blended courses. i-manager's Journal of Educational Technology, 13(1), 7-19.

Zilka, G. \& Zeichner, O. (2017). Forums and critical factors involved in feelings of challenge and threat among preservice teachers studying VCs and BCs. i-manager's Journal of Educational Technology, 13 (4).

\section{BIOGRAPHIES}
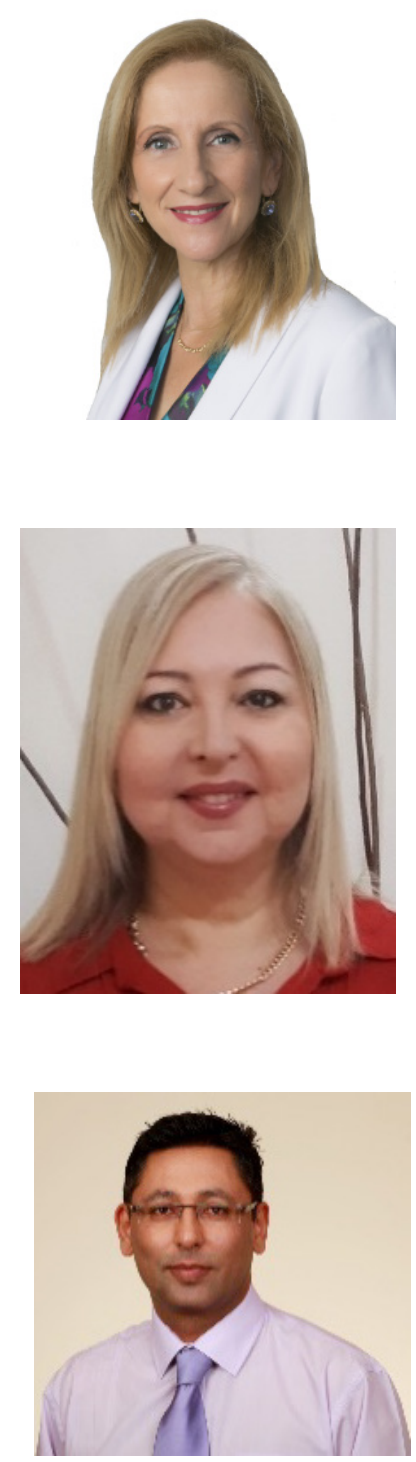

Dr. Gila Cohen Zilka, Bar-Ilan University; Achva Academic College Israel. Gila Cohen Zilka, Ph.D., Director of the Department for Teaching Social Science and Communication at Bar-Ilan University; Head of the program for training mentors to work with children at risk, Achva Academic College.

Dr. Revital Cohen, Ono Academic College, Israel.

Dr. Ilan Rahimi is the head of the Technology department studies at Ono Academic College. Dr. Ilan Daniels Rahimi is a senior lecture in The Technicon (The Israel technological institute) and a full time faculty member at the Ono Academic College. He is an expert in information systems technology implications. He also serves as the Director of Social Academic Development and as a Member of the Ono Academic College Higher Academic Committee. 